\title{
The role of pragmatic socialization in building learners' pragmatic competence from English teachers' perspectives
}

\author{
Musli Ariani ${ }^{1 *}$, Yazid Basthomi ${ }^{2}$, Johannes Ananto Prayogo ${ }^{3}$ \\ ${ }^{1}$ Universitas Negeri Malang, Jawa Timur, Indonesia \\ 2 Universitas Negeri Malang, Jawa Timur, Indonesia \\ ${ }^{3}$ Universitas Negeri Malang, Jawa Timur, Indonesia
}

\begin{abstract}
This article provides empirical evidence regarding Indonesian EFL teachers' perceptions about pragmatic competence and the role of pragmatic socialization to develop learners' pragmatic competence. Considerable viewpoints were obtained by analyzing the data collected from 104 Indonesian EFL teachers using questionnaires and focus group interviews. While still maintaining the conventional way of teaching English, these teachers admitted the importance of socializing English pragmatics to their students. They indicated that EFL learners needed to learn the socio-cultural norms of the target language in order to communicate appropriately. Teachers viewed politeness essential for learners to understand that failure to meet the required action might break interpersonal relationships. Therefore, they agreed that language classrooms should utilize interactive strategic tasks that involved learner-learner and teacher-learner interactions to foster the presence of pragmatic socialization in the classrooms. Even though most teachers were unsure about how they would put their ideas in practice, it was evident that teachers perceived both explicit and implicit language socialization processes promising and worth implementing. Future research may investigate how teachers socialize English pragmatics to EFL learners in real classroom settings.
\end{abstract}

Keywords: Explicit pragmatic socialization, Implicit pragmatic socialization pragmatic competence, Pragmatic socialization, Teachers' perceptions.

\section{INTRODUCTION}

In this globalized era, teachers of English as a foreign language in Indonesia face two crucial challenges, just like any other EFL teachers in the world particularly in Asia such as in Japan and China. Firstly, English teachers need to help learners to be pragmatically competent since they face the fact that English as a foreign language (EFL) learners are now connected to the world using English (Taguchi, 2014, 2015; Yuan, Tangen, Mills, \& Lidstone, 2015). This condition demands teachers to direct learners towards being aware of the diverse socio cultural backgrounds (Deters, 2011; Nieto, 2010). This implies the need for pragmatic awareness raising (Nguyen, Pham, \& Pham, 2012; Rose, 2009), since failure in understanding one's culture may risk social relationship, a social connection between members of a society. For instance, one may lose a good connection with another because one fails to recognize different socio-cultural backgrounds that may affect his or her way of expressing things in interaction so that misunderstanding occurs. The members of global society may share the same information, but may not get the same meaning about the information due to diverse socio-cultural backgrounds. Therefore, lacking awareness of the differences at this point may result in misunderstandings (Nieto, 2010). Secondly, EFL teachers are challenged to be able to direct EFL learners to take leadership participation in the global world (Taguchi, 2014, 2015; Wang \& Halenko, 2019; Yuan et al., 2015). EFL learners may not just become passive members of this society, but play active roles in the global membership. Hence, English may become a strategic source for learners' academic and career development. This demands teachers to become pragmatically competent English models in the classrooms (Ishihara, 2011). Thus, the need for pragmatic competence to be part of the English curriculum for English teachers and learners is inevitable. However, there has been little attention paid on pragmatic competence in Indonesian curriculum for English at all levels of education (Suryoputro \& Suyatno, 2017; Wijayanto, Prasetyarini, \& Hikmat, 2017).

Teachers need to socialize English pragmatics to develop learners' pragmatic competence. Pragmatic competence means "the ability to use language effectively in order to achieve a specific purpose and to understand language in context" (Thomas, 1983, p.92). On the other hand, linguistic competence is made up of grammatical competence which means "abstract

Corresponding Author e-mail: musliariani@gmail.com https://orcid.org/0000-0002-0753-5230

How to cite this article: Ariani M, Basthomi Y, Johannes Prayogo A, (2021). The role of pragmatic socialization in building learners' pragmatic competence from English teachers' perspectives. Pegem Journal of Education and Instruction, Vol. 11, No. 4, 2021, 197-208

Source of support: Nil

Conflict of interest: None.

DOI: 10.47750/pegegog.11.04.19

Received: 10.06.2021

Accepted: 31.08 .2021

Publication: 01.10 .2021 
or decontextualized knowledge of intonation, phonology, syntax, semantic, etc." (Thomas, 1983, p.92). This study follows a comprehensive definition of pragmatic competence stated by Taguchi that "L2 pragmatic competence refers to learners' knowledge of linguistic forms and cultural norms, as well as their ability to use the knowledge when performing social-bound functions" (Taguchi, 2014, p.161). This means that to promote pragmatic competence, EFL learners need to have linguistic skills for everyday social interaction, and they also need to have socio cultural knowledge of the target language which includes social conventions, register, and formality (Taguchi, 2014). Therefore, socialization to all the skills necessary for learners to function appropriately in the community is essential. Pragmatic socialization processes may take two forms: "socialization to use the language or socialization through the use of language" (Schieffelin \& Ochs, 1986, p.163). In other words, pragmatic socialization can be either explicit socialization or implicit socialization, respectively ( $\mathrm{Li}, 2008)$.

Explicit pragmatic socialization in EFL context has different process from that in native environment. In native environment, caregivers, parents or siblings may take most position as the ones who teach, for instance, social norms, politeness routines, and conversation rules ( $\mathrm{Li}$, 2008; Schieffelin \& Ochs, 1986). In EFL context, teachers or peers are the ones who model and give feedback or teach polite speech, social norms, how to say 'thanks', how to request, etc. Implicit pragmatic socialization occurs when beginners figure out how to become a competent member of a community by learning the socio cultural phenomena they discover in their daily interactions with people around them ( $\mathrm{Li}, 2008)$. In EFL context, learners as novices, may learn from their teachers and peers by observing what they do or by doing what the teachers or peers guide them to do in order to use English appropriately in interactions based on a given situation. Explicit and implicit socialization of English pragmatics can be done by using collaborative tasks which could be beneficial for learning pragmatic features. For instance studies conducted by Kim and Taguchi (2016) and Taguchi and Kim (2014) showed that tasks could be set for students to perform PDR-high or PDR-low speech acts by optimizing interaction between learner and learner under teacher's guidance in order to learn both sociopragmatic and pragmalinguistic features (Kim \& Taguchi, 2016; Taguchi \& Kim, 2014). Some findings of the studies show that explicit or implicit teaching of pragmatic aspects may help learners to socialize or familiarize themselves to the aspects by the help of their teachers and their peers (Alsuhaibani, 2020; Lantz-Andersson, 2017; Sánchez-Hernández, 2018; Sydorenko, Daurio, \& L. Thorne, 2017; Taguchi, 2020).

Findings of previous research have suggested important accounts of teachers' perception on pragmatic competence in relation to the successful execution process of pragmatic socialization. Some studies show promising results in which teachers are aware of the need to facilitate learners to develop their pragmatic competence. In Li's study (2000), an ESL learner was dependent on her ability to use English appropriately to survive in her new workplace. Assisted by more competent peers, the learner in the study could successfully internalize and develop communicative competence in the target language through socio cultural exposure and participation in social interactions. For the learner, her life and career was much dependent on her ability in making appropriate requests in the foreign country where she lived ( $\mathrm{Li}, 2000)$. In line with this finding, Nguyen's study (2012) revealed that an adult second language learner of English developed the ability to recognize, project, and perform the structural organization of a new communicative practice with other co-present participants. Structural organization of a communicative practice was obtained from the co-construction of interaction between participants in a talk to mutually develop the communication practice both using the language and embodied actions such as gestures, facial expressions, postural expressions, and manipulation of objects (Nguyen, 2012).

Some research findings of the studies conducted by Cohen \& Shively (2007) and Bella (2011), however, have provided counter evidence for pragmatic socialization in attempts to develop learners' pragmatic competence due to some misleading perceptions. Teachers assumed that learners would be able to pick up pragmatic norms of the language being learned by themselves as they were provided with some exposures of language and culture strategies. Nevertheless, the research results showed that intervention of language and culture strategies did not have impact on students' pragmatic performance. In a study abroad program, students improved in the use of mitigating request, but lacked awareness in acknowledging responsibility in apology, suggesting that these non-native speakers were unaware of sociopragmatic norms for what might be expected in a given situation (Cohen \& Shively, 2007)a self-study guidebook on language and culture strategies, which included strategies for learning speech acts, and electronic journaling by the students. The study used an experimental design in which the participants, all university students $(\mathrm{N}=86$. For the non-native speaker subjects, who were economic migrants in the study of invitation refusals, length of residence alone was insufficient to acquire socio cultural norms and develop pragmatic ability without intensity of interaction (Bella, 2011). In sum, socio cultural exposures and length of residence would only work successfully with the assistance of teachers and expert or more competent peers to help learners learn English pragmatics. Teachers' misunderstanding of this point may result in their failure to help learners develop their ability to select, organize and use English pragmatic features in the real-life context. 
As has been indicated by previous research findings, there is an imminent relation between teachers' perception of pragmatic competence and pragmatic socialization (Iwasaki, 2011; Taguchi, 2014; Tajeddin, Alemi, \& Pashmforoosh, 2018).

One example is seen in the case of male American L2 Japanese learners in Iwasaki's study (2011). Host people's perceptions about their social identity as informal and friendly stereotyped Americans had made the learners trapped in a difficult situation, in which they were not given sufficient feedback on if they should diverge from the norms of informal/formal politeness expressions. As a result, the L2 learners faced problems once they encountered language use of expressing politeness in Japanese (Iwasaki, 2011). Another example is shown from Taguchi's study (2014) in English medium university context. The students who were exposed to socio cultural language use in the classroom and outside the classroom, where students lived in dormitory and communicated in English with other international students, did produce strong progress in the production of informal opinions. However, ability to express opinions in formal situations did not develop. The failure in performing formal opinions was due to teachers' misleading perceptions about modes of communication. In the classroom, teachers encouraged direct modes of communication to give students opportunities to express themselves in English, thereby ignoring politeness considerations. As a result, students developed a wrong assessment of target form-function context mappings that constrained their progress. They paid less attention to socio cultural language use in formal setting (Taguchi, 2014). Results of previous studies have implied the importance of teachers' awareness and understanding of pragmatic competence; thereby, helping them conduct pragmatic socialization optimally to assist learners to produce appropriate language behavior. If teachers have clear viewpoints about pragmatic competence and pragmatic socialization, then, they will likely be able to prevent learners from committing pragmatic failure or to give some corrective feedback that can improve learners' ability in using language in socio cultural contexts.

Previous findings of studies on L2 pragmatic socialization have implied how important teachers' perception on both learners' pragmatic competence and pragmatic socialization (Bella, 2011; Cohen \& Shively, 2007; Iwasaki, 2011; Taguchi, 2014) Learners may successfully learn to pick up pragmatic features, either through explicit or implicit language socialization, with teachers' guidance. But learners may fail to do so due to misleading perceptions of teachers, host families, friends, or partners who are supposed to help them notify pragmatic features during the process of socialization. While most studies have highlighted methods and strategies in facilitating learners' pragmatic development, such as computer mediated communication to develop sociopragmatic competence, input enhancement and recast to develop constructive criticism, and implicit input condition on the development of bi-clausal request forms and their internal modification devices (Cruz, 2013; M. Nguyen, Pham, \& Pham, 2015; Takahashi, 2013, 2014), a little attention, if any, has been paid on teachers' perceptions about the role of pragmatic socialization to build learners' pragmatic competence. Even though pragmatic competence has been widely studied, studies on pragmatic competence and pragmatic socialization from teachers' perspective in an EFL context are scarcely reported, particularly in Asia, and more specifically in Indonesia.

\section{Method}

\section{Research Design}

This study employed an exploratory research design using survey and focus group interviews. The design was selected to gain meaningful information on account of current perceptions of EFL teachers on English pragmatic competence and pragmatic socialization in which little was explained within the body of knowledge. Survey and focus group interviews were utilized to grasp a better understanding regarding teachers' viewpoints on pragmatic competence and the role of pragmatic socializations to build learners' pragmatic competence.

\section{Participants}

The participants of this study were 104 (81female and 23 male) Indonesian teachers of English who resided in two eastern regencies of East Java. They were junior high school teachers who passed the in-service training program held by the Faculty of Teacher Training and Education of a university in the area under the National Program for Teacher Professional Development. There were three age groups: $25-30,31-40$, and over 40 years old. Most participants (74 teachers) aged under the first age group, 9 teachers under the second group, and 21 teachers under the last group. The average years of formal English-learning was 13 years. Years of teaching varied from less than 5 years to over 15 years. Participants voluntarily fill out the availability form and the consent form sent via English Teacher Association (MGMP). Three groups of junior high school English teachers were finally formed, each consisted of 30 teachers, 40 teachers, and 34 teachers. The groups were connected using WhatsApp groups during the questionnaire launch and completion time. It took for about fifteen days until all participants completed the questionnaire. For ethic consideration, teachers' identity is kept confidential. Therefore, pseudo names are used when teachers' names should appear in this article.

\section{Data Collection Tools}

Data for this study were collected using questionnaire and focus group interviews. Questionnaire in this study consisted 
of two parts: the demographic questions and the Likert type questions. The demographic questions tapped the information about the teachers' gender, age, years of learning English, and years of teaching English. The Likert type questionnaire consisted of ten items to collect data of teachers' perception on pragmatic competence and pragmatic socialization to build Indonesian EFL learners' pragmatic competence. The items were drawn from the literature to tap teachers' views on linguistic knowledge, language use, process of pragmatic socialization, and tasks that foster pragmatic socialization to build learners' pragmatic competence (Yuan, Tangen, Mills, \& Lidstone, 2015; Taguchi, 2014; Li, 2008; Schieffelin \& Ochs, 1986; Thomas, 1983). P articipants were a sked to select one out of five answers that range from $1=$ Strongly Disagree, $2=$ Disagree, $3=$ Neutral, $4=$ Agree, and $5=$ Strongly Agree .

The focus group interviews were intended to further explore the data about the EFL teachers' viewpoints on pragmatic competence and pragmatic socialization to develop EFL learners' pragmatic competence. The interview questions were drawn from the literature (Kim \& Taguchi, 2016;2011 Taguchi, 2014; Li, 2008) and the questionnaire data. The questions were developed from the following main questions: What is English to you? If you were English learners, what would you expect from learning it and how would you learn it? If you were English learners, how would you expect your teacher teach English in class in order that you could use English appropriately in social contexts? Considering learners' current backgrounds in globalization era, how should the teacher teach English nowadays? What is important in teaching English: teaching how to use English fluently like native speakers or how to communicate appropriately to other people?

\section{Data Collection}

The questionnaire was responded in two different ways: via the link provided by Google form and paper-based form. Participants could choose which type was convenient for them. A group of participants (Group A) responded via the link, while the other two groups and the other two groups of participants (Group B and Group C) did it on a paperbased format. The paper-based questionnaire was d elivered to the groups according to the appointment in which it was delivered on two different sessions of the same day. Sample Likert-type questions in this study were: I think that explicit teaching of politeness in English communication help students to use the language appropriately; I believe that information on culture, conversation rules, and usage on how to use English appropriately needs to be taught to student.

The interviews were conducted to the subset groups of participants. Twelve participants were invited to join the focus group interviews. There were eleven of the participants who finally joined the interviews voluntarily (four from Group A, four from Group B, and three from Group C). They, then, were grouped into two focus groups. One group consisted of six teachers and the other one consisted of five teachers. Each interview lasted for about 45 minutes to 1 hour. Interviews were conducted in English since participants had the capability of expressing themselves in English fluently during the interview sessions. Repetition and elaboration of questions were sometimes done to avoid participants' misunderstanding of the questions. Interviews were done in relaxed atmosphere to help participants express their ideas and feelings freely even with the presence of a recorder. The focus group interviews were recorded and were transcribed verbatim using Max $Q D A$ Analytics Pro. Data were coded for main and sub-categories deductively following the conceptual framework of pragmatic competence and pragmatic socialization. The collected data from the groups were compared and the overlapping data were removed to avoid redundancy. Besides, some data have been summarized for efficiency, and only the main points are presented excluding mistakes or slips of thetongue.

\section{Data Analysis}

Descriptive statistical analysis and thematic based analysis were implemented to answer two research questions. The first and the second research questions were answered by grouping the raw data obtained from the questionnaires and statistically transforming them into tables of frequency counts followed by interpretation. Further exploration was done by interpreting the results of the interviews using the thematic based analysis.

\section{FINDINGS}

Results of the survey for the questionnaire on the Likert scale questions are presented along with supporting focus group interview data. The thematic based analysis of the interview is presented on Table 1.

\section{Teachers' Perception on Pragmatic Competence}

Linguistic knowledge is essential since it functions as a tool to convey ideas in English. Apparently, teachers moderately believe in the teaching of English as teaching linguistic knowledge such as grammar rules, pronunciations and mechanics. Table 2 displays teachers' viewpoints on the aspects of linguistic knowledge. The data for Question 1 shows that a moderate number of teachers views English teaching as the teaching of linguistic knowledge. More than 50 percent of English teachers consider English teaching as teaching linguistic knowledge. Meanwhile, there is a reasonable number of teachers, 30 percent of them, believe otherwise.

The interview data indicate that teachers vary in providing support for the teaching of linguistic knowledge. Teacher 1 , for instance, stated that English teaching meant teaching grammar and vocabulary, in which both language components were taught prior to language skills. Teacher 7, however, highlighted 
Table 1: Themes for teachers' views on pragmatic competence and pragmatic socialization

\begin{tabular}{|c|c|c|c|}
\hline Theme & Sub Theme & Teachers & Teachers' views \\
\hline \multirow{10}{*}{$\begin{array}{l}\text { Pragmatic } \\
\text { Competence }\end{array}$} & \multirow{4}{*}{$\begin{array}{l}\text { Knowledge of } \\
\text { Linguistic }\end{array}$} & 1,5 & Teaching grammar and vocabulary before language skills \\
\hline & & 7 & Giving learners opportunity to practice grammar and vocabulary \\
\hline & & 11 & Teaching speaking for fluent speech and good pronunciation \\
\hline & & 3 & Integrated teaching of language skills \\
\hline & \multirow[t]{6}{*}{$\begin{array}{l}\text { Knowledge of Language } \\
\text { Use }\end{array}$} & $1,8,10$ & $\begin{array}{l}\text { Introducing learners to the cultural aspects of English and teaching how to } \\
\text { understand a message and to convey it }\end{array}$ \\
\hline & & 2,4 & Teaching how to function socially in virtual era \\
\hline & & 7,3 & Teaching how to speak to other people appropriately \\
\hline & & 11 & Directing learners to use English for their career development \\
\hline & & 6,8 & $\begin{array}{l}\text { Teaching how to understand meaning of what people say and to create mutual } \\
\text { understanding in communication }\end{array}$ \\
\hline & & 10 & $\begin{array}{l}\text { Giving learners opportunity to learn how native speakers communicate to } \\
\text { each other }\end{array}$ \\
\hline \multirow{5}{*}{$\begin{array}{l}\text { Pragmatic } \\
\text { Socialization }\end{array}$} & \multirow{3}{*}{$\begin{array}{l}\text { Process of Pragmatic } \\
\text { Socialization }\end{array}$} & 4,5 & Explicit pragmatic socialization \\
\hline & & $2,7,11$ & Implicit pragmatic socialization \\
\hline & & $1,3,6,8,10$ & Explicit and implicit pragmatic socialization \\
\hline & \multirow[t]{2}{*}{$\begin{array}{l}\text { Implementation of } \\
\text { Pragmatic Socialization }\end{array}$} & $\begin{array}{l}1,2,3,4,6,7 \\
10,11\end{array}$ & $\begin{array}{l}\text { Providing students with authentic materials (internet- based materials: music, } \\
\text { movies, stories, news, games, VLOG, popular articles,etc) }\end{array}$ \\
\hline & & $4,8,11$ & $\begin{array}{l}\text { Engaging students in interactive classes using social media to learn how to } \\
\text { build mutual understanding and to access socio-cultural aspects of English }\end{array}$ \\
\hline
\end{tabular}

Table 2: Teacher's Views on the Knowledge of Linguistics

\begin{tabular}{llllll}
\hline Question & $S D$ & $D$ & $N$ & $A$ & $S A$ \\
\hline Q1 & $1 \%$ & $33 \%$ & $8 \%$ & $45 \%$ & $13 \%$ \\
Q8 & $2 \%$ & $12 \%$ & $17 \%$ & $43 \%$ & $26 \%$ \\
Q10 & $6 \%$ & $23 \%$ & $27 \%$ & $28 \%$ & $16 \%$ \\
\hline
\end{tabular}

Note: $\mathrm{SD}=$ Strongly Disagree, $\mathrm{D}=$ Disagree, $\mathrm{N}=$ Neutral, $\mathrm{A}=$ Agree, $\mathrm{SA}=$ Strongly Agree

Question 1. I think teaching English means teaching grammatical rules, vocabulary, pronunciation, and mechanics.

Question 8. Teaching English skills such as Speaking, Listening, Reading, and Writing is best approached by giving students explanation on the meaning of unfamiliar words and grammar.

Question 10. I think it is important to lead students to be perfectly fluent in English and to have native like pronunciation.

that students did not need to learn deeper knowledge of English grammar unless students were given opportunity to practice it.

There is a significant indication that teachers focus their teaching on linguistic knowledge as shown on the table for Question 8. It appears that almost 70 percent of teachers respond that teaching English skills such as Speaking, Listening, Reading, and Writing is better approached by giving students explanation on the meaning of unfamiliar words and grammar. A small number of teachers, less than 15 percent, are aware that the conventional approach in teaching English is not the best one for teaching English skills. These viewpoints reveal a strong influence of conventional paradigm for second language learning.

The interview data indicate that giving students explanation on the meaning of unfamiliar words and grammar is still relevant with current context of English language teaching and learning. Teacher 5 stated that teaching reading was better approached by teaching vocabulary. By teaching vocabulary students would learn the meaning of the words in the reading texts. Teacher 1 came with an idea that teaching grammar and vocabulary before teaching language skills could help students learn how to structure the words. Again, teachers admit the need to teach linguistic knowledge.

Teachers' responses for Question 10 demonstrate a moderate attention on the importance of teaching linguistic knowledge. Forty four percent of the teachers think that it is important to lead students to be perfectly fluent in English and to have native like pronunciation. Only 29 per cent teachers had different perception on the question.

The interview data reveal that two teachers believe in the matter. Teacher 11, for instance, admitted that English as an international language needed to be taught to students by teaching them to speak English fluently with good pronunciation. Teacher 3 added that speaking skill was better approached in relation to other language skills and language components.

In general, most teachers view linguistic knowledge essential in teaching English as a foreign language including the teaching of grammar, vocabulary, and pronunciation. They suggest that teaching language components be done before teaching the language skills and language skills be taught in integration.

Some other teachers, however, consider that English teaching is not intended simply to make students perform English with native like pronunciation and fluency, but it is 
mainly aimed to make students know how to get a message from and deliver it to other people successfully. This is particularly necessary because students have the access to engage themselves in global communication (Teacher 2, Teacher 4, Teacher 6, and Teacher 8).

Table 3 shows teachers' viewpoints on knowledge of language use. Knowledge of language use is essential to enable learners to function in a society appropriately. As can be seen in the Question 2 row, the data show that teachers consider language use as important as linguistic knowledge. A significant proportion of teachers, 78 percent, affirm the need to teach pragmatic knowledge or how to use language in real life. At this point, it is important to see that teachers recognize the need for language use even though linguistic paradigm has occupied English teaching for substantially long period of time.

The interview data support the results of the questionnaire above in that ten out of eleven teachers admit the need to teach students how to use English appropriately according to contexts. Teachers 10 and 8 , for instance, put forward the need to teach not only the knowledge about the language and its linguistic means, but also the culture of the language for students to be able to communicate appropriately. Teacher 1 added that students could learn cultural aspects while searching for new information about the world. Teachers showed a great interest in the knowledge of language use as much as they do in linguistic knowledge.

The next data reveal a very strong perception about the need for pragmatic teaching. For Question 6, more than 90 percent of teachers respond that topics on culture, conversation rules, and appropriate usage of English in communication need to be taught to students.

The interview data indicate a support for the findings of the survey. Teachers $(2,3,4,7$, and 11) show their interest in teaching aspects of language use. Teacher 2 and Teacher 4 considered English as a part of life which was used to be socially functioning in this virtual era. Teacher 7 stated that by teaching culture in addition to teaching linguistic knowledge, students would learn how to greet people appropriately. In addition, Teacher 3 and Teacher 11 thought that English was important to pursue career development.

Table 3:Teachers' Views on Language Use

\begin{tabular}{llllll}
\hline Question & $S D$ & $D$ & $N$ & $A$ & $S A$ \\
\hline Q2 & $1 \%$ & $3 \%$ & $18 \%$ & $55 \%$ & $23 \%$ \\
Q6 & $1 \%$ & $1 \%$ & $5 \%$ & $45 \%$ & $48 \%$ \\
Q9 & $1 \%$ & $6 \%$ & $27 \%$ & $51 \%$ & $15 \%$ \\
\hline
\end{tabular}

Question 2. I think that teaching the knowledge of how to use language is as important as linguistic knowledge such as grammatical rules, vocabulary, pronunciation, and mechanics.

Question 6. I believe that topics on culture, conversation rules, and usage on how to use English appropriately needs to be taught to student.

Question 9. I believe that teaching ways to express feelings and to recognize others' state of mind is very essential in English classrooms.
As for Question 9, the data show teachers' awareness on the importance of teaching language use. In that, 66 percent teachers respond that teaching ways to express feelings and to recognize other people's feelings and emotions are very essential in English classroom, while less than 10 percent of them thought otherwise.

The interview data reflect that teachers agree that teaching English is teaching to understand what people mean by saying something. Teacher 6 stated that teaching English meant teaching meaning of what people said through their songs. Teacher 8 asserted the necessity to lead students to reach a mutual understanding when communicating using English in social media in which it might take written chat that lacked paralanguage aspects such as those found in a face-to-face interaction. People could easily be misled to a misunderstanding. Additionally, Teacher 10 stated the need to listen to native speakers of English and to communicate with them to learn how they talked to each other. These findings showed that, overall, teachers were fully aware of the importance of language use.

Most of the teachers view language use essential in teaching English as a foreign language. They put forward the need to introduce learners to the socio-cultural aspects of English to be able to express things appropriately. They also consider to direct students to function well socially in this virtual era and to take advantage of the use of English for their career development.

\section{Teachers' Perception on Pragmatic Socialization}

In accordance with the previous studies, pragmatic socialization takes two types of process: explicit and implicit socialization. Table 4 shows teachers' views on process of pragmatic socialization. The data for Question 3 reveal that teachers are aware of the need for explicit pragmatic socialization or socialization to use the language in which 88 percent of teachers have a perception that explicit teaching of politeness in English communication help students to use English appropriately.

The interview data support the results of the questionnaire in that most teachers acknowledge the need for pragmatic socialization. Five of the teachers $(1,3,6,8$, and 10) believe that pragmatic socialization can be done using both explicit and implicit approaches. Teacher 4 and Teacher 5 express

Table 4: Teachers' Views on the Process of Pragmatic Socialization

\begin{tabular}{llllll}
\hline Question & $S D$ & $D$ & $N$ & $A$ & $S A$ \\
\hline Q 3 & $1 \%$ & $1 \%$ & $10 \%$ & $50 \%$ & $38 \%$ \\
Q 7 & $0 \%$ & $3 \%$ & $6 \%$ & $46 \%$ & $44 \%$ \\
\hline
\end{tabular}

Question 3. I think that explicit teaching of politeness in English communication help students to use the language appropriately.

Question 7. It is important to give students opportunities to use English in an interaction in order to experience how to take or pass turns nicely appropriately. 
their favor of explicit approach, while Teacher 2, Teacher 7, and Teacher 11 favor the implicit one.

Teachers who agreed with the explicit approach stated that pragmatic socialization could be conducted by directly explaining to the students how to use English appropriately using internet-based authentic materials to give real examples and natural language input from the primary sources. Teacher 3 , for instance, thought of creating cultural-based activities to teach students English culture. The teacher explained that the cultural-based materials could help students learn how to engage in an interaction with other people to build a relationship. Teacher 4 suggested the use of social media to teach how foreigners converse with each other and engaged learners with readings of internet-based materials to learn about English culture. Meanwhile, Teachers 6, 8, and 10 believed the importance of setting joyful and motivating learning conditions while leading students to learn how to communicate politely and nicely with other people. They also asserted that teaching students how to use language in real life could help students identify native speakers' culture. Therefore, exposing the students to authentic spoken and written language as well as showing the cultural aspects would help them learn the target culture. The interview data show teachers' concerns about the need to make students notify the interpersonal consequences of failure in comprehending or in implementing the target language norms if they should encounter socio cultural contexts.

A strong impact is reported on Question 7 about implicit pragmatic socialization. The data indicate that 90 percent of the teachers consider it important to give students the opportunities to use English in an interaction to experience how to take part in a socially bound interaction appropriately.

As has been stated earlier, teachers also think it worth to socialize pragmatic by using the language (implicit approach). The interview data show that teachers acknowledge the importance of giving students the opportunities to use English in an interaction to learn to communicate well in a social interaction., like to take or pass turn appropriately. Teachers stated that English culture could be subconsciously learned (Teacher 2) by giving students opportunities to practice English with other people in real life, like communicating with foreigners or native speakers of English (Teacher 7) and by leading them to the differences of how native speakers spoke to older people or to younger ones, because the way how they addressed people were different from how Indonesians commonly did it (Teacher 10). Teacher 11 highlighted the need to make students interested in English, love it, use it in communication and do things with it. In this way students would learn to communicate appropriately by picking up English pragmatic aspects. This is evident that teachers recognize implicit mode of pragmatic socialization.

Table 5 indicates teachers' views on the implementation of pragmatic socialization to develop learners' pragmatic
Table 5: Teachers' Views on the Implementation of Pragmatic Socialization

\begin{tabular}{llllll}
\hline Question & $S D$ & $D$ & $N$ & $A$ & $S A$ \\
\hline Q4 & $1 \%$ & $13 \%$ & $22 \%$ & $42 \%$ & $21 \%$ \\
Q5 & $0 \%$ & $11 \%$ & $22 \%$ & $46 \%$ & $23 \%$ \\
\hline
\end{tabular}

Question 4. I prefer to give tasks that provide opportunity for students to improve their ability to use English appropriately.

Question 5. I think my students need to engage in interactive tasks to practice communicating using English, with grammar or vocabulary focused when needed.

competence. The implementation of which is realized in two ways: free types of tasks for the implicit approach (Question 4) and guided interactive tasks for the explicit approach (Question 5).

The data demonstrate significant preferences of teachers on tasks that can foster students' engagement in using English appropriately. For Question 4, more than 60 percent of the teachers choose to use tasks that provide students with opportunity to learn knowledge and skills of English which lead them to the ultimate function of the language. In contrast, there is a weak perception reported for Question 4, where less than 20 percent of the teachers display rejection.

The interview data reveal that teachers assert the need to provide tasks that facilitate students to improve their ability to communicate appropriately. Most of the teachers have one thing in common about ways of implementing pragmatic socialization in their classroom, that is, providing students with authentic materials containing sociocultural aspects of English. The authentic materials that they mention mainly include internet-based materials, such as music, movies, stories, news, games, VLOG, popular articles, and the like either accessed from the social media such as Facebook, Skype, Instagram, YouTube, or from the websites (teachers: 1, 2, 3, 4, $6,7,10$, and 11). Teacher 3 suggested the use of Facebook to communicate with foreigners, not necessarily native speakers of English, to learn to use English in real life. Teacher 10 stated that watching native speakers' talk with each other on YouTube VLOG could help students pick up how native speakers conversed and learn the cultural aspects of the language.

As for Question 5, the data suggest a remarkable impact. Around 70 percent of the teachers respond that teaching English need to concentrate on interactive tasks that provide opportunities for students to communicate using English. Explanation on grammar or vocabulary is given in a certain circumstance. On the other hand, less than 15 percent of the teachers indicate otherwise.

The interview data show that teachers indicate the need to set interactive classes to help students learn to communicate well and to guide students to pick up cultural and linguistic aspects of English. Teacher 4, for instance, stated that allowing students to do tasks that involve written chat with foreigners 
via social media could help students learn to reach mutual understanding. While doing so, students could be directed to pay attention to the idiomatic expressions that people used in the chat. Teacher 8 suggested the use of authentic materials from YouTube such as reality shows, news program, and stories. Teacher 11 added that such authentic materials could be used to guide students to learn not only summary writing and moral values of the stories, but also sociocultural aspects and speaking skill. Unfortunately, these teachers did not illustrate how the materials were set into interactive tasks.

These findings reveal that most English teachers consider pragmatic socialization important for their students to improve their pragmatic competence. Teachers suggest the use of internet-based authentic materials, even though they are still dependent mostly on the use of English textbooks. Some teachers stated that focusing on linguistic knowledge help students improve their language skills (Teachers: 1, 2, 5, and 9). Interestingly, most teachers have also shown a good grasp on the need to teach both linguistic and pragmatic aspects of English. Teachers can explain how to conduct pragmatic socialization, even though they hardly clearly illustrate how they will implement the socialization in the classrooms.

\section{Discussion}

In all, these findings reveal that teachers' perceptions are convergent regarding pragmatic competence and pragmatic socialization to develop learners' pragmatic competence.

\section{Teacher's views on the knowledge of linguistics}

The findings suggest that a reasonable number of teachers are holding on linguistic knowledge as the main feature in teaching English as a foreign language. This is understandable. As a matter of fact, scholars world widely have been in deep influence of conventional linguistic paradigm with the focus of teaching and learning language independent of the context of its use (Watson-Gegeo, 2004). The promising point is that some teachers who are not in the same position have shown that the functions of English are manifolds. The mentions of social media and the students' interaction with people from other countries suggest teachers' awareness of cross-cultural communication in the global world. This is consistent with previous study that approach in language teaching or acquisition has shifted from traditional linguistic to language use (Duff, 2007; LantzAndersson, 2017; Taguchi, 2014; Watson-Gegeo, 2004).

Teachers seem to be fully aware of the fact that English needs to be taught in reference to context. Therefore, explaining unfamiliar words or grammar may not be needed in classroom unless it is necessary. Learners are supposed to guess the meaning of words through contexts of its use. The same case applies for grammar. Learners may learn meaning and use of grammar or vocabularies from stories, for instance.
These findings highlight that even though teachers in general still hold on linguistic knowledge and are affected by conventional approach, their awareness on the importance of language use due to current circumstance seems to be burning. Teachers' perception about English and its functions nowadays might lead their direction to pragmatic socialization. This finding support previous research in the field of L2 pragmatic socialization which are mostly triggered by cross cultural communication failure in this globalized era (Taguchi, 2014; Taguchi, 2015; Bella, 2011).

\section{Teachers' views on language use}

The findings of this research show that teachers identify the combination of both the language use and linguistic knowledge as important knowledge for EFL learners. However, teachers seem to be aware that knowledge of language use is urgent for learners to learn. This insight supports the previous research findings that knowledge of language use is important to select and to perform English appropriately in a given situation (Holmes \& Riddiford, 2011; Li, 2008; Schieffelin \& Ochs, 1986; Sydorenko, Daurio, \& L. Thorne, 2017). It is empirically evident that most teachers believe in the need to direct EFL learners to know about the English culture, conversation rules, and recognition of moods and emotions of other people in order to achieve mutual understanding in an interaction. Moreover, teachers have a mandatory duty to lead EFL learners to notify that pragmatic failure may result in communication breakdown (Lee, 2015; Ochs \& Shohet, 2007).

Most of EFL teachers in this study are aware of the need to teach their students English pragmatics even though they are unsure of how to realize their knowledge in their classes. Teachers think it is necessary for learners to know about socio cultural norms of the target language. They also acknowledge that the importance of using language appropriately is to minimize interpersonal misunderstandings or to build and maintain relationships. These findings are in line with previous studies in which $\mathrm{L} 2$ pragmatics has become the focus of learning a language (Watson-Gegeo, 2004), and that implementation needs practice (Lee, 2015). These research findings challenge teachers, particularly those who have practiced conventional methods by teaching linguistic knowledge without reference to socio cultural contexts, to stay out of their box and to leave their comfort zone for a breakthrough in English language teaching.

\section{Teachers' views on process of pragmatic socialization}

These findings suggest that teachers believe in both: explicit and implicit pragmatic socialization. Even though teachers barely show how both types of language socialization process differ; they indicate the need to teach learners politeness and turns mechanisms to communicate appropriately and successfully. Teachers point out that explicit teaching is 
necessary for EFL learners to notify which expressions are suitable for a certain circumstance; and implicit teaching will be essential to lead learners to experience using English by interacting with their peers. Teachers asserted significant differences between English and Indonesian culture. For instance the address terms I and you in English and saya, a $\mathrm{ku}$, $k a m u$ and $a n d a$ in Indonesian. The address terms are quite an issue in interaction as reported in the previous studies. The address terms play crucial role in an interaction since they determine the notion of politeness (Sukarno, 2015;no one discusses how Javanese respond to compliments politely. The aim of this study is to investigate the politeness strategies as applied to respond to compliments by the Javanese people in Jember, East Java. The notion of politeness plays crucial role in the realization of speech acts (utterances and verbal communication Susanto, 2014)for example, to designate the person they are talking to or to show the possession of formal and informal manners. However, the use of this address terms may have different interpretation across regions. This research is undertaken to find out (1. This issue had made it clear that pragmatic socialization is worth trying.

\section{Teachers' views on the implementation of pragmatic socialization}

As for the implementation of pragmatic socialization, EFL teachers have pinpointed some useful information to develop EFL learners' pragmatic competence. Teachers have mentioned the use of social media, YouTube, and other relevant home page from the World Wide Web to engage globally and to access authentic materials for learning target language norms. Nevertheless, they do not give specific information on how to develop materials and learning activities that can provide experience for learners to boost their pragmatic competence. In a way, they assert the importance of interaction for students during teaching and learning process; in another, they appear to be vague about how to execute their ideas in the actual class. These findings imply that teachers need skill training to put their knowledge into practice. Thereby, the results of this study confirm the previous research findings that even in the native environment, length of residence and exposures $s$ does not impact learning unless interaction is intensified (Bella, 2011) and exposures are notified (Cohen \& Shively, 2007)a self-study guidebook on language and culture strategies, which included strategies for learning speech acts, and electronic journaling by the students. The study used an experimental design in which the participants, all university students $(\mathrm{N}=86$ by teachers and peers. To achieve this, teachers should be skillful in managing and directing learners to take part actively in the classroom activities.

The promising point is that teachers are aware that providing students with tasks that give students chances to interact with their peers is essential for pragmatic development.
This point makes sense of the findings from the previous study on collaborative tasks. The more complex the task is, the more pragmatic related episodes are possibly found; and this means there is more chance for learners to pick up language use (Kim \& Taguchi, 2015;complex, or control. Both task groups performed a pretest, 2 collaborative tasks, and 2 posttests, whereas the control group performed the pre- and posttests only. Learners' oral interaction during tasks was audiorecorded and analyzed by the number of pragmatic-related episodes (PREsTaguchi \& Kim, 2014)control group $(\mathrm{n}=24$. Technology can play its part when direct interaction is not possible due to social distancing by setting "digital learning spaces such as structured, semistructured, and unstructured" (Taguchi, 2020:354)

Referring to the objectives of this research on how EFL teachers perceive pragmatic competence; and what their viewpoints are on pragmatic socialization to build EFL learners' pragmatic competence; the research findings reveal the following points.

Based on EFL teachers' perceptions, it is important to understand English as a means of communication in which pragmatic competence plays key role in EFL teaching and learning context. EFL learners need to use English in order to function appropriately in the society where they live. Failure to bring the norms into practice will likely bring interpersonal consequences, like communication breakdown.

Pragmatic socialization is a promising approach to help Indonesian EFL learners develop their English pragmatic competence. Teachers consider that pragmatic socialization process allows learners to learn knowledge of linguistics and language use together with teachers and their peers in a classroom as a community.

EFL teachers recognize some ways to develop EFL learners' pragmatic competence including two types of pragmatic socialization process, explicit and implicit pragmatic socialization, that can be applied in EFL classrooms. Explicit socialization can be carried out by explicit teaching of pragmatic features; while implicit socialization can be done by engaging learners with tasks that demand pragmatic related episodes. In this way, learners can learn both linguistic knowledge and knowledge of language use which are essential for learners if they should encounter appropriate language use in socio cultural contexts.

Further, EFL teachers underline some considerable details about English teaching and learning in relation to globalization. There are good opportunities for EFL learners to learn English pragmatics for free by the help of technology. Teachers and learners may access authentic materials using internet, they may also engage in global interaction with people in the world using social media, games, and other relevant tools for global communication. 


\section{CONCLUSION}

The findings of the study indicate that EFL teachers' perceptions of English pragmatic competence have shown promising insights in relation to English language teaching. Most teachers recognize the importance of the teaching of pragmatics or language use. Although some teachers still have the tendency of focusing teaching on linguistic knowledge, such as grammar, vocabulary, and pronunciation, in isolation of its use in context, their interest in the importance of teaching English to enable learners to communicate appropriately have opened the opportunities for a new approach to be manifested in teaching English as a foreign language.

EFL teachers' viewpoints reveal their understanding and awareness of the roles of pragmatic socialization to build learners' pragmatic competence. They acknowledge several roles of pragmatic socialization that are urgent for EFL learners. Firstly, introducing learners to the culture of the target language can help learners to be aware of what to do and what to say in a specific cultural situation. Secondly, providing learners with strategic interactive tasks can provide students with the opportunities to use the language with other people. Thirdly, socializing pragmatic features of English, either explicitly or implicitly, can raise learners' awareness of the features so that they will be aware of what linguistic means need to be selected for a certain context. On top of this, teachers recognize that the ideal teaching demands learner-learner and teacher-learner collaborative interactions to boost pragmatic socialization to be present in the classroom. More importantly is the learners' awareness on the consequences for interpersonal relationship if failures should occur. However, teachers imply that they hardly know how to develop methods and techniques that are compatible to the above roles of pragmatic socialization for the actual classroom implementation.

The findings fill up the void on account of information regarding EFL teachers' perspectives on pragmatic competence and pragmatic socialization. The results of the research reveal that EFL teachers' view pragmatic competence essential for EFL learners, since it leads learners to the understanding of the use of language in context. The findings also show that teachers are aware of the need for pragmatic socialization. Even though teachers imply that they have not yet implemented the approach, teachers acknowledge some learning sources that can be used to do the socialization. This piece of information adds to the body of knowledge in interlanguage pragmatics in which the information is hardly found in the previous piles of literature. The findings, hence, have answered the research questions. The EFL teachers' see pragmatic competence and pragmatic socialization crucial for teaching language as a means of global communication and interaction.

\section{SUGGESTION}

The findings of this study have shed light on the directions of EFL teaching. The findings suggest that EFL teachers socialize English pragmatics to their students. To help teachers do so, further research is needed to investigate teachers' level of pragmatic competence and to explore whether their classrooms practice involve students in pragmatic socialization. Since classroom in Indonesia is most commonly the only possible place for the socialization of English pragmatic, classroom activities should reflect social activity types that represent real life experiences for learners.

\section{Limitation}

This study, however, has some limitations. Since Indonesia is rich of sociocultural varieties, involving participants from eastern part of East Java only may not represent how teachers from a wider range of areas with various sociocultural backgrounds perceive English pragmatic competence and its socialization. Besides, participants aged 25 to 30 years were predominant in this study. Teachers in this age are assumed to be technologically literate and so most of them can speak about authentic materials and access of the information from the World Wide Web. Even though these viewpoints give a promising implication for future teaching, the generalizability of the data is untenable. Finally, a more in-depth interviews might have drawn a better picture about teachers' viewpoints in relation to English pragmatics and its socialization process in EFL classrooms.

\section{References}

\section{Journal Article}

Alsuhaibani, Z. (2020). Developing EFL students' pragmatic competence: The case of compliment responses. Language Teaching Research, (85), 1-20. https://doi. org/10.1177/1362168820913539

Bella, S. (2011). Mitigation and politeness in Greek invitation refusals : Effects of length of residence in the target community and intensity of interaction on non-native speakers' performance $\$$. Journal of Pragmatics, 43, 1718-1740. https://doi.org/10.1016/j. pragma.2010.11.005

Cohen, A. D., \& Shively, R. L. (2007). Acquisition of requests and apologies in Spanish and French: Impact of study abroad and strategy-building intervention. Modern Language Journal, 91(2), 189-212. https://doi.org/10.1111/j.15404781.2007.00540.x

Cruz, S. (2013). Say what?! L2 Sociopragmatic Competence in CMC : Skill Transfer and Development. CALICO Journal, 30(3), 423-445. https://doi.org/10.11139/cj.30.3.423-445

Deters, P. (2011). Identity, Agency and the Acquisition of Professional Language and Culture. London: Continuum International Publishing.

Duff, P. a. (2007). Second language socialization as sociocultural theory: Insights and issues. Language Teaching, 40(04), 309319. https://doi.org/10.1017/S0261444807004508 
Holmes, J., \& Riddiford, N. (2011). From classroom to workplace : tracking socio-pragmatic development. ELT Journal, 65(4), 376-386. https://doi.org/10.1093/elt/ccq071

Ishihara, N. (2011). Co-Constructed Pragmatic Awareness: Instructional Pragmatics in EFL Teacher Development in Japan. The Electronic Journal for English as a Second Language (TESL-EJ), 15(2).

Iwasaki, N. (2011). Learning L2 Japanese 'politeness' and 'impoliteness': Young American men's dilemmas during study abroad. Japanese Lanuage and Literature, 45(2011), 67-106. Retrieved from http://eprints.soas.ac.uk/11678/

Kim, Y., \& Taguchi, N. (2015). Promoting Task-Based Pragmatics Instruction in EFL Classroom Contexts: The Role of Task Complexity. Modern Language Journal, 99(4), 656-677. https:// doi.org/10.1111/modl.12273

Kim, Y., \& Taguchi, N. (2016). Learner-Learner Interaction During Collaborative Pragmatic Tasks: The Role of Cognitive and Pragmatic Task Demands. Foreign Language Annals, 49(1), 42-57. https://doi.org/10.1111/flan.12180

Lantz-Andersson, A. (2017). Language play in a second language: Social media as contexts for emerging Sociopragmatic competence. Education and Information Technologies, 23(2), 705-724. https://doi.org/10.1007/s10639-017-9631-0

Lee, H. (2015). Telling stories and making social relations: Transnational women's ways of belonging in intercultural contexts. Applied Linguistics, 36(2), 174-193. https://doi. org/10.1093/applin/amt038

$\mathrm{Li}, \mathrm{D}$. (2000). The pragmatics of making requests in the $\mathrm{L} 2$ workplace: A case study of language socialization. Canadian Modern Language Review/La Revue Canadienne Des Langues Vivantes, 57(1), 58-87. https://doi.org/10.3138/cmlr.57.1.58

Li, D. (2008). Pragmatic Socialization. In P. A. Duff \& N. H. Hornberger (Eds.), Encyclopedia of Language and Education (2nd ed., Vol. 8, pp. 71-83). Springer Science+Business Media LLC.

Nguyen, H. (2012). Social interaction and competence development : Learning the structural organization of a communicative practice Hanh thi Nguyen *. Learning, Culture and Social Interaction, 1, 127-142. https://doi.org/10.1016/j.lcsi.2012.05.006

Nguyen, M., Pham, H., \& Pham, T. (2015). The effects of input enhancement and recasts on the development of second language pragmatic competence. Innovation in Language Learning and Teaching, (April 2015), 37-41. https://doi.org/ 10.1080/17501229.2015.1026907

Nguyen, T. T. M., Pham, T. H., \& Pham, M. T. (2012). The relative effects of explicit and implicit form-focused instruction on the development of L2 pragmatic competence. Journal of Pragmatics, 44(4), 416-434. https://doi.org/10.1016/j.pragma.2012.01.003

Nieto, S. (2010). Language, Culture, and Teaching (2nd ed.). New York: Taylor \& Francis.

Ochs, E., \& Shohet, M. (2007). The Cultural Structuring Of Mealtime Socialization. New Directions for Child and Adolescent Development, 2006(111), 35-49. https://doi.org/ $10.1002 / \mathrm{cad}$

Rose, K. R. (2009). Pragmatics in teacher education for nonnative - speaking teachers: A consciousness - raising approach. Language, Culture and Curriculum, 10(2), 125-138. https:// doi.org/10.1080/07908319709525246

Sánchez-Hernández, A. (2018). A mixed-methods study of the impact of sociocultural adaptation on the development of pragmatic production. System, 75, 93-105. https://doi.org/10.1016/j. system.2018.03.008

Schieffelin, B. B., \& Ochs, E. (1986). Language Socialization. Annual Reviews of Anthropology, 15, 163-191. https:/doi. org/10.1177/1046878108317399

Sukarno, S. (2015). Politeness Strategies in Responding To Compliments in Javanese. Indonesian Journal of Applied Linguistics, 4(2), 91-101. https://doi.org/10.17509/ijal.v4i2.686

Suryoputro, G., \& Suyatno. (2017). Pragmatics Role in the EFL Teaching to Indonesian Junior and Senior High School Students. International Journal of Language and Linguistics, 4(2), 53-59.

Susanto, D. (2014). Tthe Pragmatic Meanings of Address Terms Sampeyan and Anda. Indonesian Journal of Applied Linguistics, 4(1), 140-155. https://doi.org/10.17509/ijal.v4i1.606

Sydorenko, T., Daurio, P., \& L. Thorne, S. (2017). Refining pragmaticallyappropriate oral communication via computer-simulated conversations. Computer Assisted Language Learning, 31(1-2), 157-180. https://doi.org/10.1080/09588221.2017.1394326

Taguchi, N. (2014). Pragmatic socialization in an English-medium university in Japan. IRAL - International Review of Applied Linguistics in Language Teaching, 52(2), 157-181. https://doi. org/10.1515/iral-2014-0007

Taguchi, N. (2015). Cross-cultural adaptability and development of speech act production in study abroad. International Journal of Applied Linguistics, 25(3), 343-365. https://doi.org/10.1111/ ijal.12073

Taguchi, N. (2020). Digitally mediated remote learning of pragmatics. Foreign Language Annals, 53(2), 353-358. https://doi. org/10.1111/flan.12455

Taguchi, N., \& Kim, Y. (2014). Collaborative dialogue in learning pragmatics: Pragmatic-related episodes as an opportunity for learning request-making. Applied Linguistics, 37(3), 416-437. https://doi.org/10.1093/applin/amu039

Tajeddin, Z., Alemi, M., \& Pashmforoosh, R. (2018). Idealized native-speaker linguistic and pragmatic norms in English as an international language: exploring the perceptions of nonnative English teachers. Language and Intercultural Communication, 18(3), 300-314. https://doi.org/10.1080/14708477.2017.1413105

Takahashi, S. (2014). The effects of learner pro files on pragmalinguistic awareness and learning. System, 48(February), 48-61. https:// doi.org/10.1016/j.system.2014.09.004

Thomas, J. (1983). Cross Cultural Pragmatic Failure. Applied Linguistics, 4(2), 91-112. https://doi.org/10.1093/applin/4.2.91

Wang, J., \& Halenko, N. (2019). Longitudinal benefits of predeparture pragmatics instruction for study abroad: Chinese as a second/foreign language. East Asian Pragmatics, 4(1), 87-111. https://doi.org/10.1558/eap.38216

Watson-Gegeo, K. A. (2004). Mind, Language, and Epistemology: Toward a Language Socialization Paradigm for SLA. The Modern Language Journal, 88(3), 331-350. https://doi. org/10.1111/j.0026-7902.2004.00233.x

Wijayanto, A., Prasetyarini, A., \& Hikmat, M. H. (2017). Impoliteness in EFL: Foreign Language Learners' Complaining Behaviors Across Social Distance and Status Levels. SAGE Open, 7(3), 1-15. https://doi.org/10.1177/2158244017732816

Yuan, Y., Tangen, D., Mills, K. A., \& Lidstone, J. (2015). Learning English Pragmatics in China: An Investigation into Chinese EFL Learners' Perceptions of Pragmatics. The Electronic Journal of English as a Second Language (TESL-EJ, 19(1), 1-16. 
